\title{
Pertumbuhan Kalus Eksplan Rimpang Jahe Merah (Zingiber officinale Rosc.) pada Berbagai Konsentrasi Sukrosa Secara In Vitro
}

\section{The Growth Callus of Red Ginger (Zingiber officinale Rosc.) Explant on Different Sucrose Concentration In Vitro}

\author{
Ilma Kherasani ${ }^{1}$, Erma Prihastanti ${ }^{2}$, Sri Haryanti ${ }^{2}$ \\ ${ }^{1}$ Program Studi Biologi, Departemen Biologi, Fakultas Sains dan Matematika, Universitas Diponegoro \\ ${ }^{2}$ Departemen Biologi, Fakultas Sains dan Matematika, Universitas Diponegoro \\ Jl. Prof. Soedarto, SH, Tembalang, Semarang \\ *Email : eprihast@yahoo.co.id
}

Diterima 10 Agustus 2016/Disetujui 17 Februari 2017

\begin{abstract}
ABSTRAK
Sukrosa adalah disakarida yang merupakan produk fotosintesis tidak langsung. Penelitian ini dilakukan dengan metode in vitro dengan cara inisiasi kalus untuk menginduksi kalus dari eksplan mata tunas rimpang jahe merah (Zingiber officinale Rosc). Konsentrasi senyawa osmotik dari medium menjadi faktor penting untuk pertumbuhan kalus. Selain sebagai sumber karbon dan sumber energi, sukrosa yang terserap mempengaruhi tekanan osmotik sehingga berperan dalam pemanjangan sel. Penelitian ini dilaksanakan dengan menggunakan Rancangan Acak Lengkap (RAL) dengan satu faktor yaitu variasi konsentrasi sukrosa. Konsentrasi sukrosa sebagai perlakuan adalah $20 \mathrm{~g} / 1$ (S1); $30 \mathrm{~g} / \mathrm{l}$ (S2); $40 \mathrm{~g} / \mathrm{l}$ (S3); dan $50 \mathrm{~g} / 1$ (S4), masingmasing 5 ulangan. Peningkatan berat basah kalus tertinggi diperoleh pada perlakuan konsentrasi sukrosa 30 g/l. Sedangkan berat kering kalus tertinggi diperoleh pada perlakuan konsentrasi sukrosa $50 \mathrm{~g} / \mathrm{l}$, semakin banyak jumlah sukrosa dalam media maka semakin besar berat kalus. Namun berdasarkan uji statistik ANOVA, pemberian variasi konsentrasi pada pertumbuhan kalus menunjukkan tidak berbeda nyata. Hasil penelitian menunjukkan bahwa warna kalus yang diamati dari konsentrasi yang berbeda menunjukkan warna putih kekuningan dan dengan tekstur remah.
\end{abstract}

Kata kunci : Zingiber officinale Rosc, pertumbuhan, kalus, sukrosa

\begin{abstract}
Sucrose is a disaccharide which is a product of indirect photosynthesis. Sucrose serves as forming the cell components and energy sources.This research was conducted by in vitro method of callus initiation to induce callus from the explant buds rhizome of Zingiber officinale Rosc. Osmotic compound concentration of the medium is an important factor for the growth of callus. Aside from being a source of carbon and energy sources, absorbed sucrose affecting the osmotic pressure that play a role in cell elongation. This study was conducted using a completely randomized design (CRD) with one factor varying concentrations of sucrose. Sucrose concentration as the treatment is $20 \mathrm{~g} / 1$ (S1); $30 \mathrm{~g} / 1$ (S2); $40 \mathrm{~g} / 1$ (S3); and $50 \mathrm{~g} / 1$ (S4), each 5 replicates. The highest increase in callus fresh weight was obtained at treatment concentrations of sucrose $30 \mathrm{~g}$ / 1. While the dry weight obtained at the highest callus treatment of sucrose concentration of $50 \mathrm{~g} / \mathrm{l}$, increasing of sucrose number in the media is equivalent with callus weight. However, based on ANOVA statistical test, various concentrations on the callus growth showed no significant difference. The results showed that the callus observed color from different concentrations showed a yellowish white color and crumb texture.
\end{abstract}

Keywords : Zingiber officinale Rosc, growth, callus, sucrose 


\section{PENDAHULUAN}

Jahe merah (Zingiber officinale Rosc.) merupakan salah satu komoditas ekspor penting dan bahan baku obat tradisional serta fitofarmaka yang banyak digunakan dalam industri obat herbal di Indonesia. Komoditas ini juga berperan cukup berarti dalam penyerapan tenaga kerja dan penerimaan devisa negara.

Rendahnya variabilitas genetik plasma nutfah jahe, menyebabkan peluang untuk memperoleh sumber gen ketahanan terhadap penyakit layu bakteri oleh Pseudomonas solonacearum semakin kecil. Pengujian pada tiga tipe jahe, menunjukkan bahwa jahe gajah paling peka terhadap penyakit layu bakteri, sedangkan jahe merah paling toleran (Hadad et al., 1989). Penurunan produksi disebabkan oleh turunnya produksi di sentra pengembangan jahe utama (Jawa Barat) akibat serangan organisme pengganggu tanaman (OPT) dan budidaya yang kurang optimal (BPS, 2004). Salah satu upaya yang dapat dilakukan untuk mengatasi masalah penyakit tular benih, adalah menyediakan benih sehat bebas penyakit melalui kultur jaringan (In vitro).

Konsentrasi senyawa osmotik dari medium menjadi faktor penting untuk pertumbuhan kalus. Umumnya produksi kalus meningkat pada medium yang tekanan osmotiknya tinggi (Percy et al., 2000). Tekanan osmotik tersebut dapat ditentukan oleh sukrosa, yang juga berfungsi sebagai sumber karbon (Van Creij et al., 1999). Pendewasaan embrio dapat diperoleh dengan cara mengkulturkan massa pro- embriogenk pada konsentrasi sukrosa 20 g/l- 50 g/l. Sukrosa yang dihidrolisis oleh enzim invertase menjadi glukosa dan fruktosa, akan menjadi substrat yang diperlukan untuk pertumbuhan (Merkle et al., 1990).

Penelitian regenerasi melalui tahapan pembentukkan kalus telah dilaporkan dalam beberapa penelitian terdahulu, salah satunya yaitu pengaruh variasi konsentrasi sukrosa terhadap pertumbuhan dan induksi embriogenesis somatik kultur kalus tapak dara, memberikan pengaruh yang signifikan terhadap berat kering kalus, yaitu pada konsentrasi sukrosa $40 \mathrm{~g} / 1$ sebesar $0,037 \mathrm{~g}$ yang berbeda nyata dengan semua perlakuan. Peningkatan berat kering kalus seiring dengan peningkatan konsentrasi sukrosa yaitu 0- $40 \mathrm{~g} / \mathrm{l}$ (Herwinaldo, 2009). Serta Gati dan Mariska (1988) mendapatkan bahwa eksplan yang ditanam pada media yang diperkaya dengan BAP membentuk kalus kompak, media terbaik yang mengandung $10 \mathrm{mg} / \mathrm{l}$ BAP dan $0,1 \mathrm{mg} / \mathrm{l}$ NAA. Tujuan penelitian ini adalah Mengetahui pengaruh konsentrasi sukrosa yang berbeda terhadap pertumbuhan kalus eksplan mata tunas rimpang jahe merah Zingiber officinale Rosc. Mengetahui konsentrasi sukrosa yang optimal untuk pertumbuhan kalus eksplan mata tunas rimpang Zingiber officinale Rosc.

\section{METODE PENELITIAN}

Bahan yang digunakan dalam penelitian ini dikelompokkan dalam tiga kelompok sesuai dengan jenis dan cara penggunaannya.

a. Media Tanam

Media dasar yang digunakan adalah Murashige \& Skoog (MS). Bahan yang dibutuhkan untuk membuat media MS. Jenis media tanam berupa gel padat, menggunakan agar- agar khusus yang tidak berwarna dan bersifat netral.

b. Bahan Sterilisasi

Bahan yang digunakan untuk mensterilkan peralatan adalah alkohol $70 \%$, aquades, spiritus (api), korek api, dan tisu.

c. Eksplan Tanaman

Bahan tanaman yang digunakan sebagai eksplan adalah mata tunas rimpang Zingiber officinale Rosc. dalam media MS dengan karakteristik rimpang segar (tidak ada bercak kecoklatan), memiliki 2 mata tunas dalam setiap rimpang. Rimpang diambil dari perkebunan Tani Sejahtera desa Tanjungkalang Kec. Ngronggot, Kab. Nganjuk, Jawa Timur. Bagian tanaman yang digunakan adalah mata tunas.

Eksplan mata tunas ditimbang untuk mengetahui ukuran eksplan, sehingga diperoleh eksplan yang seragam untuk ditanam. Berat 
eksplan yang digunakan sekitar 0,4 - 0,46 g. Eksplan mata tunas rimpang jahe merah direndam dalam sabun anti bakteri konsentrasi 3tetes/100 ml selama 24 jam kemudian Eksplan mata tunas direndam ke dalam larutan anti jamur selama 60 menit. Langkah selanjutnya sterilisasi dilakukan di dalam LAF dengan merendam eksplan ke dalam Clorox 10\% selama 20 menit dan dibilas aquades steril. Kemudian direndam lagi ke dalam Clorox 5\% selama 25 menit. Selanjutnya eksplan direndam ke dalam larutan alkohol 96\% selama 30 detik dan dibilas aquades steril secara bertahap dengan waktu perendaman 10 menit, 5 menit dan 3 menit.

Parameter yang diamati yaitu : berat basah kalus, dan berat kering kalus, morfologi kalus (warna dan tekstur kalus). Untuk mendapatkan berat kering konstan, kalus dikeringkan dalam oven dengan suhu $50^{\circ} \mathrm{C}$ dan ditimbang selama 2 hari sampai diperoleh berat yang konstan. Sedangkan berat basah kalus didapatkan dengan cara menimbang langsung kalus segar yang dikeluarkan dari botol menggunakan timbangan analitik. Warna kalus diamati secara visual, sedangkan tekstur kalus diamati pada saat kalus dikeluarkan dari botol kultur untuk ditimbang dengan cara menyentuhnya menggunakan pinset.

\section{HASIL DAN PEMBAHASAN}

\section{Berat Basah Kalus}

Eksplan mata tunas rimpang Zingiber officinale Rosc. pada media inisisasi terlihat mengalami perkembangan pada hari ke- 7 (1 minggu). Dan kalus mulai terbentuk pada minggu ke- 2 setelah penanaman. Hasil analisis berat basah kalus mata tunas rimpang Zingiber officinale Rosc. pada media Murashige \& Skoog (MS) dengan variasi konsentrasi sukrosa yaitu $20-50 \mathrm{~g} / 1$ disajikan pada Tabel 1. Uji ANOVA pada taraf signifikansi 95\% menunjukkan bahwa pemberian variasi konsentrasi sukrosa tidak berpengaruh nyata terhadap peningkatan berat basah kalus eksplan mata tunas rimpang Zingiber officinale Rosc.

Tabel 1 menunjukkan bahwa secara keseluruhan media perlakuan mampu meningkatkan berat basah kalus. Media dengan konsentrasi sukrosa 40 g/l (S3) menghasilkan pertumbuhan kalus tertinggi. Rata- rata peningkatan berat basah kalus pada media ini sebesar 0,65 g/l. Namun, berat basah mengalami penurunan pada konsentrasi sukrosa $50 \mathrm{~g} / \mathrm{l}$ dengan rata- rata berat basah kalus sebesar 0,492 g/l. Medium MS yang mengandung sukrosa $40 \mathrm{~g} / \mathrm{l}$ menghasilkan rata- rata berat basah tertinggi, meskipun perbedaan yang terjadi tidak signifikan Sukrosa dengan konsentrasi lebih tinggi dari komposisi normal medium MS justru menunjukkan penurunan berat basah kalus. Hal ini disebabkan konsentrasi medium menjadi lebih pekat dan menghambat penyerapan air maupun garam mineral yang ada. Peristiwa penghambatan penyerapan air tersebut lebih tampak pada penambahan sukrosa $50 \mathrm{~g} / \mathrm{l}$. Namun demikian menurut Maretzki (1984) respon pertumbuhan sel terhadap penambahan karbohidrat setiap spesies berbeda.

Tabel 1. Rata- rata Berat Basah Kalus Zingiber officinale Rosc. pada media MS dengan variasi konsentrasi sukrosa.

\begin{tabular}{cc}
\hline Konsentrasi sukrosa & Berat kalus $(\mathrm{g})$ \\
\hline $\mathrm{S} 1(20 \mathrm{~g} / \mathrm{l})$ & 0,404 \\
$\mathrm{~S} 2(30 \mathrm{~g} / \mathrm{l})$ & 0,484 \\
$\mathrm{~S} 3(40 \mathrm{~g} / \mathrm{l})$ & 0,650 \\
$\mathrm{~S} 4(50 \mathrm{~g} / \mathrm{l})$ & 0,492 \\
\hline
\end{tabular}

Penurunan berat basah kalus yang terjadi pada konsentrasi sukrosa $50 \mathrm{~g} / \mathrm{l}$ (S4) diduga disebabkan adanya cekaman kekeringan pada medium sehingga menghambat pertumbuhan kalus. Menurut Kramer (1983) cekaman kekeringan akan menghambat pertumbuhan. Cekaman kekeringan akan menyebabkan turunnya potensial air dan tekanan turgor sehingga perluasan dan pembelahan sel juga terhambat. Cekaman kekeringan juga mengganggu berbagai proses metabolik dan bisa berujung pada kematian.

Kalus yang mengalami cekaman akan mengalami gangguan metabolisme. Matheka et al., (2008) menambahkan bahwa penurunan pertumbuhan kalus diduga disebabkan oleh penurunan volume sitoplasma dan vakuola sebagai akibat keluarnya air dari sitoplasma yang disebabkan oleh penurunan potensial air di sel. 
Penurunan potensial air di sel mengakibatkan penyerapan air dan mineral dari media terhambat.

Cekaman kekeringan juga mengganggu metabolisme nitrogen. Hal ini tentunya juga berdampak langsung pada pertumbuhan kalus. Secara umum cekaman kekeringan akan menghidrolisis protein dan mengakumulasikan berbagai asam amino. Selain itu cekaman kekeringan juga akan menghambat sintesis protein dari asam amino dengan menghambat kerja enzim yang berperan dalam sintesis protein (Kramer, 1983).

Pada tabel 1 juga menunjukkan bahwa pada konsentrasi sukrosa $40 \mathrm{~g} / \mathrm{l}$ (S3) menunjukkan kenaikan berat basah kalus yang paling tinggi dari perlakuan lainnya. Hal ini diduga disebabkan karena kalus mampu beradaptasi terhadap cekaman yang diterimanya. Menurut Manfield dan Atkinson (1990) respon tanaman terhadap stres air sangat ditentukan oleh tingkat stres yang dialami dan fase pertumbuhan tanamann saat mengalami cekaman.

\section{Berat Kering Kalus}

Hasil uji ANOVA pada taraf signifikansi 95\% menunjukkan bahwa pemberian variasi konsentrasi sukrosa tidak berpengaruh nyata terhadap peningkatan berat kering kalus eksplan mata tunas rimpang Zingiber officinale Rosc. Hasil analisis berat kering kalus mata tunas rimpang Zingiber officinale Rosc. pada media Murashige \& Skoog (MS) dengan variasi konsentrasi sukrosa yaitu $20-50 \mathrm{~g} / \mathrm{l}$ disajikan pada Tabel 2.

Pemberian sukrosa $50 \mathrm{~g} / \mathrm{l}$ (S4) mampu menghasilkan berat kering kalus tertinggi yaitu sebesar 0,272 g/l. Berat kering kalus mengalami peningkatan seiring dengan peningkatan konsentrasi sukrosa dalam media. Hal ini disebabkan semakin banyak sukrosa, maka sumber karbon dan energi yang diperoleh oleh sel eksplan semakin banyak sehingga pembelahan sel, pembesaran sel, serta diferensiasi sel akan semakin baik. Didalam tubuh tumbuhan sukrosa akan terhidrolisis menjadi glukosa dan fruktosa. Glukosa akan diproses melalui glikolisis dan siklus krebs hingga menghasilkan energi berupa ATP dan
NADH, sedangkan fruktosa berperan sebagai antioksidan dalam menjaga stabilisasi membran (Strum, 1999). Sukrosa yang ditambahkan dalam media akan berfungsi sebagai bahan baku dalam proses respirasi oleh sel- sel eksplan untuk dapat melakukan aktivitas sel (Wirahadikusumah, 1985). ATP yang dihasilkan dalam glikolisis akan digunakan untuk berbagai proses yang membutuhkan energi, karena ATP merupakan molekul penyimpan energi. Sedangkan NADH nantinya akan menjalani proses transfer elektron untuk menghasilkan ATP.

Tabel 2. Rata- rata berat kering kalus Zingiber officinale Rosc. pada media MS dengan variasi konsentrasi sukrosa

\begin{tabular}{cc}
\hline Konsentrasi sukrosa & Berat kalus $(\mathrm{g})$ \\
\hline $\mathrm{S} 1(20 \mathrm{~g} / \mathrm{l})$ & 0,224 \\
$\mathrm{~S} 2(30 \mathrm{~g} / \mathrm{l})$ & 0,242 \\
$\mathrm{~S} 3(40 \mathrm{~g} / \mathrm{l})$ & 0,258 \\
$\mathrm{~S} 4(50 \mathrm{~g} / \mathrm{l})$ & 0,272 \\
\hline
\end{tabular}

\section{Warna dan Tekstur Kalus pada Media Perlakuan}

Media Inisiasi merupakan media MS dengan konsentrasi sukrosa yang berbeda. Pengamatan dilakukan 4 hari sekali selama satu bulan. Setelah satu bulan, diamati dan dibuat data pada warna maupun tekstur kalus yang terbentuk. Data warna maupun tekstur kalus disajikan dalam tabel 3, sementara morfologi kalus disajikan pada tabel 4 .

Morfologi kalus eksplan mata tunas rimpang jahe merah yang dihasilkan pada tiap konsentrasi sukrosa menunjukkan tekstur dan warna yang sama. Kondisi kalus yang dihasilkan mempunyai tekstur remah (Tabel 3) dan berwarna putih kekuningan (Tabel 4). Kalus dengan tekstur remah menunjukkan bahwa untuk inisiasi kalus mata tunas rimpang jahe merah pada konsentrasi sukrosa 20- $50 \mathrm{~g} / \mathrm{l}$ sudah mampu untuk membentuk tekstur kalus yang remah. Kalus yang remah memiliki ciri- ciri dengan tekstur yang mudah dipisahkan. Terbentuknya kalus berstruktur remah dipicu oleh adanya hormon auksin endogen yang diproduksi secara internal oleh eksplan yang telah timbul membentuk kalus tersebut. Terbentuknya kalus yang remah ini juga dipengaruhi oleh 
penambahan sitokinin (BAP) dalam media. Menurut Syahid et al., (2010), adanya sitokinin dapat meningkatkan pembelahan sel membentuk kalus. Jadi, terbentuknya kalus yang remah merupakan hasil aktivitas pembelahan sel yang meningkat. Terbentuknya kalus disebabkan adanya rangsang luka. Rangsang tersebut menyebabkan kesetimbangan pada dinding sel berubah arah, sebagian protoplas mengalir ke luar sehingga mulai terbentuk kalus. Kalus terbentuk pada bagian eksplan yang terluka (potongan). Pemberian konsentrasi sukrosa membuat kalus yang terbentuk merata pada semua permukaan eksplan. Hal ini diduga karena pada media dengan penambahan sukrosa, sumber karbon dan energi didapatkan lebih banyak sehingga proses pembelahan sel- sel eksplan dan pembentukkan kalus maksimal

Tabel 3. Warna dan tekstur kalus Zingiber officinale Rosc. pada media perlakuan

\begin{tabular}{ccccc}
\hline & S1 & S2 & S3 & S4 \\
\hline \multirow{6}{*}{ Warna } & PK (1) & PK (1) & PK (1) & PK (1) \\
& PK (2) & PK (2) & PK (2) & PK (2) \\
& PK (3) & PK (3) & PK (3) & PK (3) \\
& PK (4) & PK (4) & PK (4) & PK (4) \\
& PK (5) & PK (5) & PK (5) & PK (5) \\
\hline \multirow{6}{*}{ Tekstur } & Remah (1) & Remah (1) & Remah (1) & Remah (1) \\
& Remah (2) & Remah (2) & Remah (2) & Remah (2) \\
& Remah (3) & Remah (3) & Remah (3) & Remah (3) \\
& Remah (4) & Remah (4) & Remah (4) & Remah (4) \\
& Remah (5) & Remah (5) & Remah (5) & Remah (5) \\
\hline
\end{tabular}

Keterangan : PK : Putih Kekuningan

Tabel 4. Deskripsi Morfologi Kalus

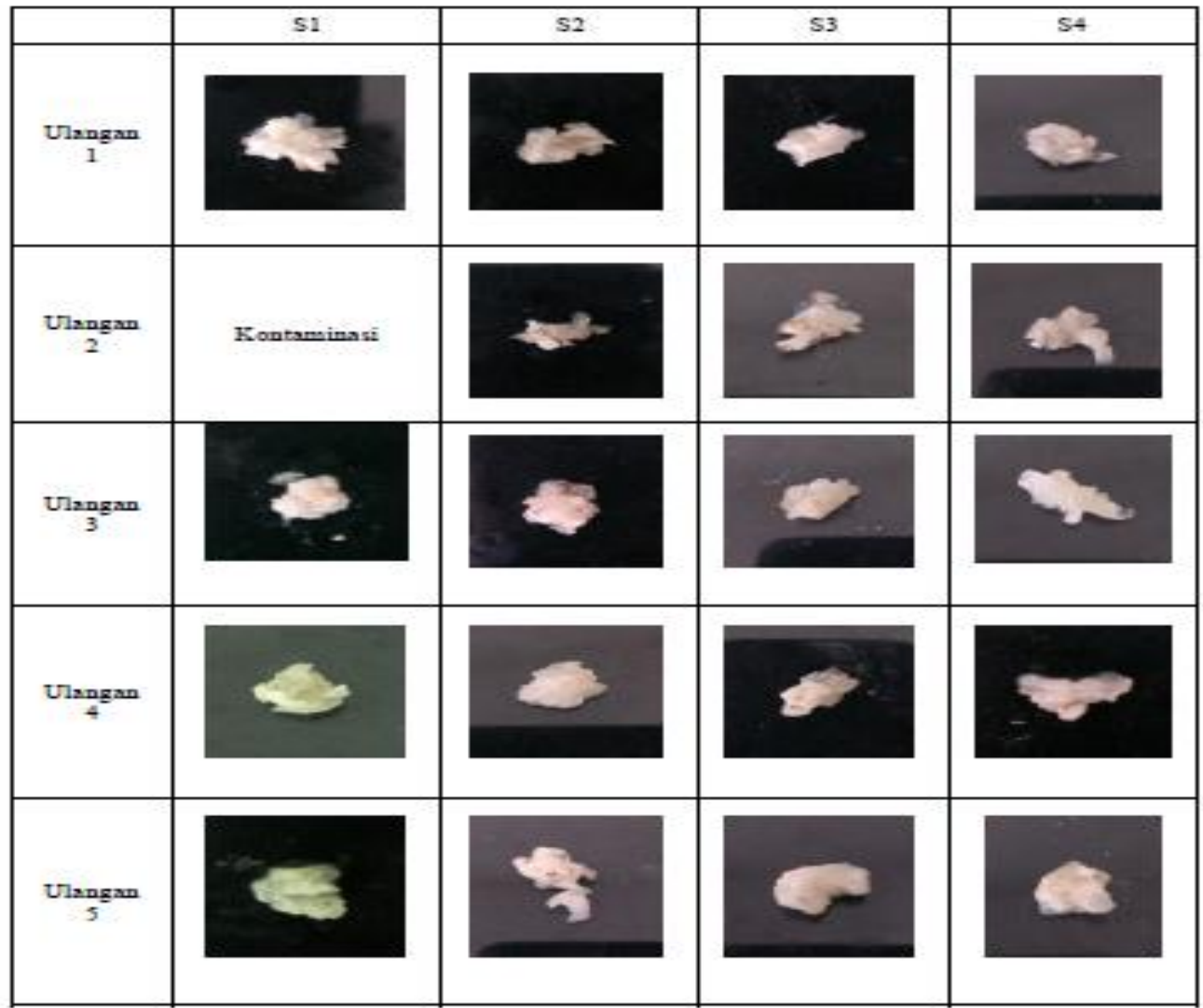


Terbentuknya kalus disebabkan adanya rangsang luka. Rangsang tersebut menyebabkan kesetimbangan pada dinding sel berubah arah, sebagian protoplas mengalir ke luar sehingga mulai terbentuk kalus. Kalus terbentuk pada bagian eksplan yang terluka (potongan). Pemberian konsentrasi sukrosa membuat kalus yang terbentuk merata pada semua permukaan eksplan. Hal ini diduga karena pada media dengan penambahan sukrosa, sumber karbon dan energi didapatkan lebih banyak sehingga proses pembelahan sel- sel eksplan dan pembentukkan kalus maksimal.

Warna putih merupakan warna awal saat kalus mulai mengalami inisiasi. Warna kalus menunjukkan tingkat perkembangan kalus yang terbentuk. Menurut Gamborg (1982) warna kalus yang terbentuk antara lain kuning, kehijauan, dan hijau terang. Kalus yang berwarna putih tidak mengandung kloroplas, tetapi mengandung plastid yang berisi butir pati yang sedikit demi sedikit tumbuh menjadi sistem membran yang jelas yang akhirnya terbentuklah proto klorofil dengan paparan cahaya, sehingga kalus menjadi berwarna kekuningan sampai hijau. Warna terang atau putih dapat mengindikasikan bahwa kondisi kalus masih cukup baik. Menurut Kresnawati (2006), warna kalus dari suatu eksplan dipengaruhi oleh zat pengatur tumbuh. Warna kalus yang bermacammacam diakibatkan oleh adanya pigmentasi cahaya dan asal eksplan.

\section{KESIMPULAN}

Peningkatan konsentrasi sukrosa dalam media MS cenderung meningkatkan pertumbuhan kalus Zingiber officinale Rosc. yang ditunjukkan pada berat basah dan berat kering kalus.

\section{DAFTAR PUSTAKA}

Badan Pusat Statistik (BPS). 2007. Statistik Perdagangan Indonesia : Impor. Jilid ke-1. Jakarta : Biro Pusat Statistik.

BPS. 2003 sampai 2011. Statistik Tanaman Biofarmaka. BPS. Jakarta, 76 hlm.
BPS. 2011. Statistik Tanaman Biofarmaka. BPS. Jakarta, 76 hlm.

Benson. L. 1957. Plant Classification.D.C Heath and Co. Boston.

Darnell, J., H. Lodish and H. Baltimore. 1986. Molecular Cell Biology. Scientific American Books, Inc. New York.

Dodds, J.H., dan L.W. Robert. 1983. Experiment in Plants Tissue Culture. Cambridge University Press. London.

Dwidjoseputro, D. 1994. Dasar- Dasar Mikrobiologi. Djambatan, Jakarta.

Fakhrai HK, Fakhrai F. 1990. Hormon Control of Growth and Development. Methods in Molecular Biology Plant Cell and Tissue Culture. Jeffrey W Pollard, John M Walker (editor). The Humana Press. New Jersey.

Gati, E dan Mariska, I. 1988. Perbanyakan Cepat Jahe Merah melalui Teknik Kultur Jaringan. Bul. Littro Vol. III No. 1. Hal 35-38.

George, E.F., and P.D. Sherrington. 1984. Plant Propagation by Tissue Culture. Handbook and Directory of Commercial Laboratories. Exegenetic Limited. England.

George, EF. 1993. Plant Propagation by Tissue Culture, Part I. Exergetics Limited, Edington, Wilts, England. 574p.

Kusnawidjaja, Kurnia. 1987. Biokimia. Forum Perpustakaan Umum Indonesia, BPAD Jambi.

Lukito, A. M. 2007. Petunjuk Praktis Bertanam Jahe. Agromedia Pustaka, Jakarta.

Pierik, R.I.M. 1987. In Vitro Culture of Higher Plants : 119. Netherland : Martinus Nijhoff Publisher.

Rostiana, O dan S.F. Syahid, 2007a. Pengaruh media dasar MS dan N6 terhadap perkembangan embrio somatik pada kultur meristem jahe (Zingiber officinale Rosc.). Berita Biol. 9 (2) (In press). 
Stepan- Sarkissian G. 1990. Selection of Media for

Tissue and Cell Culture. Methods in Molecular Biology Plant Cell and Tissue Culture. Jeffrey W Pollard, John M Walker (editor). The Humana Press. New Jersey.

Wattimena, GA. 1992. Bioteknologi Tanaman. Departemen P dan K. Dirjen Pendidikan Tinggi. PAU Bioteknoloogi Bogor.

Wettherel DF. 1982. Pengantar Propagasi Tanaman secara In Vitro. Terjemahan Koensoemardiyah. Fakultas Farmasi Universitas Gajah Mada. Yogyakarta. 